\title{
Physical Metallurgical Studies of Zr-Rich U-Zr Alloys
}

\section{Bagchi AC*, Prasad GJ, Khan KB and Singh RP}

Nuclear Fuels Group, Bhabha Atomic Research Centre, Trombay, Mumbai 400085, India

\begin{abstract}
Uranium-zirconium alloy is considered main ingredient for making metallic fuel for Fast Breeder Reactor. Also, Zr-rich U-Zr alloys find applications in dispersion fuel for advance PWR. In this work investigations were carried out on the zirconium rich uranium-zirconium alloys (i.e. U-50wt\%Zr, U- 60wt\%Zr and U-70wt\%Zr) in as-cast as well as in heat treated conditions. Microstructural and dilatometric studies were carried out along with X-ray Diffraction Analysis (XRD) to evaluate the phase content as well as the phase transformation behavior of these alloys under different heat treated conditions.
\end{abstract}

Keywords: Uranium; Zirconium; Casting; Heat treatment; Scanning electron microscope; Energy dispersive X-ray spectroscopy

\section{Introduction}

The major metallic fuels for fast breeder reactor are $\mathrm{U}-\mathrm{Pu}-\mathrm{Zr}$ or $\mathrm{U}-\mathrm{Zr}-\mathrm{Nb}[1]$ ternary alloy system, where $\mathrm{U}-\mathrm{Zr}$ is the major sub-system. Uranium-zirconium alloys are main constituents for making metallic fuels. These fuels find their use in monolithic form for fast reactor and in dispersion form in thermal reactor [2,3]. With suitable enrichment of uranium, zirconium rich $\mathrm{U}-\mathrm{Zr}$ alloys could be used as dispersion fuel in advanced pressurized water reactor. The zirconium rich $\mathrm{U}-\mathrm{Zr}$ alloys exhibit excellent thermal conductivity and higher solidus temperature. Uranium alloys are usually preferred in as-cast condition for reactor fuel since mechanical working can induce unwanted texture in it and subsequent irradiation induced growth. Studies on irradiation properties of uranium-zirconium alloys have been reported [4-6], but there have been very few studies of physical metallurgy of the uranium zirconium alloys [7]. Small numbers of open literatures are available which report a comprehensive study on influence of $\mathrm{Zr}$ concentration on the various physical properties of U-rich $\mathrm{U}-\mathrm{Zr}$ alloys. Lagerberg [8] has reported the phase transformation behavior in $\mathrm{U}-2 \mathrm{wt} \% \mathrm{Zr}$ and recently the same is re-evaluated by Basak et al. [9]. Transformation behaviour on quenching of different $\mathrm{U}-\mathrm{Zr}$ alloys is described by Hills et al. [10]. Discussion on properties like microhardness, thermal properties, variation of lattice parameters for alloy up to $\mathrm{U}-10 \mathrm{wt} \% \mathrm{Zr}$ are also reported by Basak [10,11].

\section{Uranium-Zirconium system}

Liquid uranium solidifies at $1135^{\circ} \mathrm{C}$. Solid elemental uranium exhibits three polymorphic forms; namely, bcc $\gamma$ phase $\left(>776^{\circ} \mathrm{C}\right)$, tetragonal $\beta$ phase (between $668^{\circ} \mathrm{C}$ and $776^{\circ} \mathrm{C}$ ) and orthorhombic a phase $\left(<668^{\circ} \mathrm{C}\right)$. Whereas $\mathrm{Zr}$ has two allotropes high temperature bcc $\beta$ phase $\left(>863^{\circ} \mathrm{C}\right)$ and hcp $\alpha$ phase $\left(<863^{\circ} \mathrm{C}\right)$ under atmospheric pressure. In $\mathrm{U}-\mathrm{Zr}$ system, $\gamma$ phase exhibits full mutual solid solubility of $U$ with $\beta Z$ r. The $U-Z r$ phase diagram is presented in figure 1 . There is only one intermetallic $\delta$ phase that is formed at temperatures about $617^{\circ} \mathrm{C}$ by a peritectoid reaction $\alpha+\gamma^{\prime \prime} \rightarrow \delta$ with a nominal composition of UZr2. The $\delta$ phase has a $\omega$-type structure (space group $P 6 / \mathrm{mmm}$ ), in which the corner positions $\left(\begin{array}{lll}0 & 0 & 0\end{array}\right)$ are occupied by $\mathrm{Zr}$ atoms and the sites $(1 / 3,2 / 3,1 / 2)$ and $(2 / 3,1 / 3,1 / 2)$ are randomly shared by $U$ and $\mathrm{Zr}$ atoms. The $\delta$ phase is not a line compound but has a composition range of $42.5-57.5 \mathrm{wt} \% \mathrm{Zr}$ at $400^{\circ} \mathrm{C}$, as can be seen from the phase diagram (Figure 1). The present investigation deals mostly with the comparison of the properties related to physical metallurgy in the Zr-rich U-Zr alloys with $\mathrm{Zr}$ concentration of $50 \mathrm{wt} \% 60 \mathrm{wt} \%$ and 70 $\mathrm{wt} \%$. The paper reports the as-cast and heat treated microstructures of Zr-rich U-Zr alloys. Variations in lattice parameters and densities, derived from the XRD analysis, are reported here as a function of $\mathrm{Zr}$ concentration. Dilatometric results are also presented here and equations of the thermal expansion are derived for these alloys. Also inferences are drawn regarding the phase transformation behavior of these alloys from the microstructures, XRD analysis and dilatometric results. Referring to the $\mathrm{Zr}$-rich part of $\mathrm{U}-\mathrm{Zr}$ phase diagram (Figure 1 ), it is easy to find that the choice of the present alloy compositions encompasses the eutectoid line. From the U-Zr diagram at $606^{\circ} \mathrm{C}$, it is observed that $\gamma-(\mathrm{U}, \mathrm{Zr})-\mathrm{BCC}$ decomposes into $\mathrm{aZr}-\mathrm{HCP}$ and $\sim \delta$-UZr2-Hexagonal. Heat treatment of the cast sample temperature

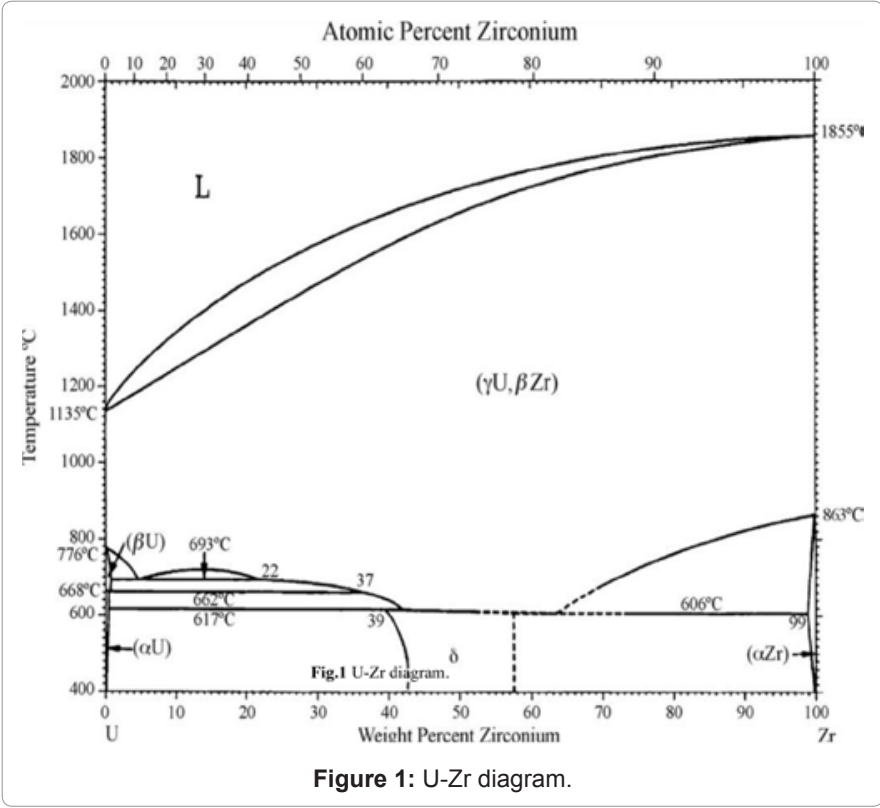

*Corresponding author: Bagchi AC, Nuclear Fuels Group, Bhabha Atomic Research Centre, Trombay, Mumbai, India, Tel: +91-22-25591520; Fax: +91-2225505151; E-mail: acbagchi@hotmail.com, acb@barc.gov.in

Received November 26, 2012; Accepted December 27, 2012; Published January 04, 2013

Citation: Bagchi AC, Prasad GJ, Khan KB, Singh RP (2013) Physical Metallurgical Studies of Zr-Rich U-Zr Alloys. J Material Sci Eng 2:121. doi:10.4172/2169 0022.1000121

Copyright: @ 2013 Bagchi AC, et al. This is an open-access article distributed under the terms of the Creative Commons Attribution License, which permits unrestricted use, distribution, and reproduction in any medium, provided the original author and source are credited. 
is selected below Peritectoid/Eutectoid line. This is because it is expected that due to fast cooling while preparation of casting sample, composition of alloy will remain as per above the eutectoid line (Figure 1). Heating the sample for 24 hours below Peritectoid/Eutectoid line and slow (furnace) cooling will bring it to equilibrium condition.

Details of phase diagram: Liquidus-solidus: A continuous increase in their temperatures with increase in zirconium fraction. The top of the miscibility gap exists at $720^{\circ} \mathrm{C}$ and $14 \mathrm{wt} \% \mathrm{Zr}$ At $693^{\circ} \mathrm{C}$ the reaction at the miscibility gap could be presented as $\gamma(14 \mathrm{wt} \% \mathrm{Zr}) \rightarrow$ $\gamma \Phi(4.8 \mathrm{wt} \% \mathrm{Zr})+\gamma^{2}(22 \mathrm{wt} \% \mathrm{Zr})$. Oxygen and/or nitrogen were noted to have a pronounced effect on the temperature and composition limits of the miscibility gap; increasing concentrations enlarged the region with respect to both temperature and composition [12]. The phase diagram exhibits monotectoid, eutectoid, peritectoid and again eutectoid isotherms at $693^{\circ} \mathrm{C}, 662^{\circ} \mathrm{C}, 617^{\circ} \mathrm{C}$ and $606^{\circ} \mathrm{C}$ respectively. Temperatures and $\mathrm{Zr}$ concentrations corresponding to the different reaction isotherms are summarized in table 1.

\section{Alloy Sample Preparations}

Melting of any $\mathrm{Zr}$ containing alloy sample in general poses difficulty owing to the fact that $\mathrm{Zr}$ is a good oxygen getter. So, during the alloy melting it must be ensured that no gaseous impurity comes from the outside into the melting chamber. It is thus advisable to melt lab scale $\mathrm{U}-\mathrm{Zr}$ alloys in a chamber pressurized with argon or helium rather than under high vacuum. In the present study arc melting practices is used for preparation of the samples.

Uranium rods were obtained from Atomic Fuels Division, BARC, and India in various diameters $(2 \mathrm{~mm}$ to $12.5 \mathrm{~mm})$ and length. Zirconium, on the other hand, was procured from Nuclear Fuel Complex (NFC), Hyderabad, India. For alloy preparation amount of zirconium was adjusted against the weight of the uranium. Chemical composition of the uranium and zirconium used are given in table 1. Each U-Zr alloy finger was melted six to eight times turning the button upside-down after each melting to ensure chemical homogeneity. In order to ensure oxygen free environment during the arcmelting a pure $\mathrm{Zr}$ button was melt before each melting cycle. The copper mould is constantly cooled to avoid overheating of the alloy and ensuring cooling of the as cast sample. The alloy finger obtained was sealed in quartz capsule that had been evacuated at room temperature to about $1 \times 10^{-2} \mathrm{~Pa}$ and then filled with high-purity argon just above atmospheric pressure. The fingers were first homogenized at $550^{\circ} \mathrm{C}$ for 24 hours and then quenched in water. (From figure 1 it is observed that equilibrium state achieved is below temperature line $606^{\circ} \mathrm{C} / 617^{\circ} \mathrm{C}$ keeping $\sim 50^{\circ} \mathrm{C}$ as uncertainty on furnace temperature detection margin, $550^{\circ} \mathrm{C}$ as the homogenized temperature.)

Chemical analysis of these alloys was carried out using ICP-AES (Inductively Coupled Plasma-Atomic Emission Spectroscopy) for the impurity analysis of the pure uranium, pure zirconium (Table 1) and impurities of U-Zr alloys (Table 2). For carbon, oxygen and nitrogen analysis standard $\mathrm{CNO}$ analyzer was used.

The characterization of the alloy was carried out by XRD and metallography. For the metallographic and XRD analyses, the samples were cut from the finger into pieces of suitable thickness using slow speed $\mathrm{SiC}$ abrasive cut-off wheel. Standard metallographic techniques of U-Zr alloys are given in detail in ASM metal handbook [13]. CuKa radiation was used for XRD analysis with fixed slit optics and $\mathrm{q}-\mathrm{q}$ goniometer.

\section{Microstructural and XRD analysis}

For the metallographic and XRD analyses, the alloy sample was cut into disc of suitable thickness using slow speed $\mathrm{SiC}$ abrasive cut-off wheel. Standard metallographic techniques were adopted for grinding and polishing. Electro-etching was carried out using $5 \% \mathrm{H}_{3} \mathrm{PO}_{4}$ aqueous solution as electrolyte and SS304 as cathode with a constant potential of $2 \mathrm{~V}$. The microstructural analysis was carried out using a Scanning Electron Microscope (SEM) and an Energy Dispersive Spectroscope (EDS). $\mathrm{Cu}-\mathrm{Ka}$ radiation was used for XRD analysis with fixed slit optics and q-q goniometer. Diffraction patterns were obtained with a step size of 0.0080 and a dwell time of $2 \mathrm{~s}$.

\section{Dilatometry}

The expansion behaviour of U-Zr was studied using a high temperature vertical dilatometer (make: SETARAM Instrumentation, France; model: Setsys Evoluation 24).The heating rate used for the present study was $5^{\circ} \mathrm{C} \mathrm{min}^{-1}$. Here, the sample is loaded inside a sample holder which is made of $\mathrm{Al}_{2} \mathrm{O}_{3}$. The change of the length of the sample was transmitted through the frictionless push rod to an LVDT transducer. The samples were machined to $10 \mathrm{~mm}$ diameter and then cut into parallel-sided cylinder. A nominal load of $5 \mathrm{~g}$ was chosen to be applied by the push rod over the sample. A calibrated thermocouple was placed to record the sample temperature. The dilatometric experiments were carried out in high purity argon atmosphere at a dynamic gas flow rate of $2 \mathrm{dm} 3 \mathrm{~h}^{-1}$.

\section{Chemical analysis}

Chemical analysis of these alloys was carried out in ICP-AES (Inductively Coupled Plasma-Atomic Emission Spectroscopy) for the determination of $\mathrm{Zr}$ and other metallic impurities. For non-metallic impurities, e.g. carbon, oxygen and nitrogen, standard C/N/O analyzer was used.

\section{Results and Discussion}

Table 1 shows the typical chemical composition of uranium and zirconium, the starting material. Uranium is in ingot form and zirconium is in sponge flake form. Table 2 shows the details of samples prepared.

\section{Microstructure}

Figure 2 shows the typical microstructures of $\mathrm{Zr}$-rich $\mathrm{U}-\mathrm{Zr}$ alloys

\begin{tabular}{|c|c|c|c|c|c|c|c|c|c|c|c|c|}
\hline Material & $\mathrm{Zr}$ & $\mathrm{U}$ & $\mathrm{C}$ & $\mathrm{N}$ & $\mathrm{O}$ & $\mathrm{Y}$ & $\mathrm{Fe}$ & $\mathrm{Ni}$ & $\mathrm{Cr}$ & $\mathrm{Mg}$ & $\mathrm{Mn}$ & $\mathrm{Ce}$ \\
\hline uranium & - & Rest & 252 & 32 & 188 & 105 & 64 & 15 & 11 & 16 & 8 & 6 \\
\hline zirconium & Rest & - & 27 & 10 & 227 & 12 & 120 & 60 & 44 & 10 & - & - \\
\hline
\end{tabular}

Table 1: Typical chemical composition of uranium and zirconium in wppm.

\begin{tabular}{|c|c|c|c|}
\hline & Nominal composition(wt \%) & Weighted composition(wt \%) & Weight, gm \\
\hline 1 & $\mathrm{U}: 50 \mathrm{Zr}$ & $\mathrm{U}: 49.90 \mathrm{Zr}$ & 21.14 \\
\hline 2 & $\mathrm{U}: 60 \mathrm{Zr}$ & $\mathrm{U}: 60.44 \mathrm{Zr}$ & 22.46 \\
\hline 3 & $\mathrm{U}: 70 \mathrm{Zr}$ & $\mathrm{U}: 69.98 \mathrm{Zr}$ & 21.04 \\
\hline
\end{tabular}

Table 2: Details of sample composition found through EDS.

\begin{tabular}{|c|c|c|c|}
\hline & Nominal composition(wt \%) & As cast sample & Heat treated sample \\
\hline 1 & $\mathrm{U}: 49.90 \mathrm{Zr}$ & 145 & 488 \\
\hline 2 & $\mathrm{U}: 60.44 \mathrm{Zr}$ & 251 & 817 \\
\hline 3 & $\mathrm{U}: 69.98 \mathrm{Zr}$ & 307 & 390 \\
\hline \multicolumn{2}{|c|}{ Table 3: Grain Size in $\mu \mathrm{m}}$. \\
\hline
\end{tabular}




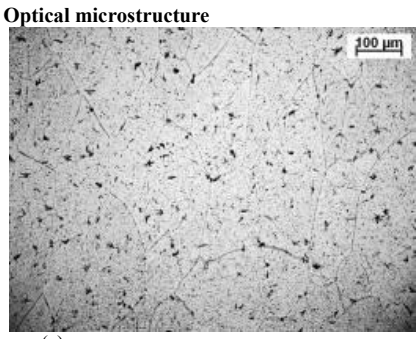

(a)
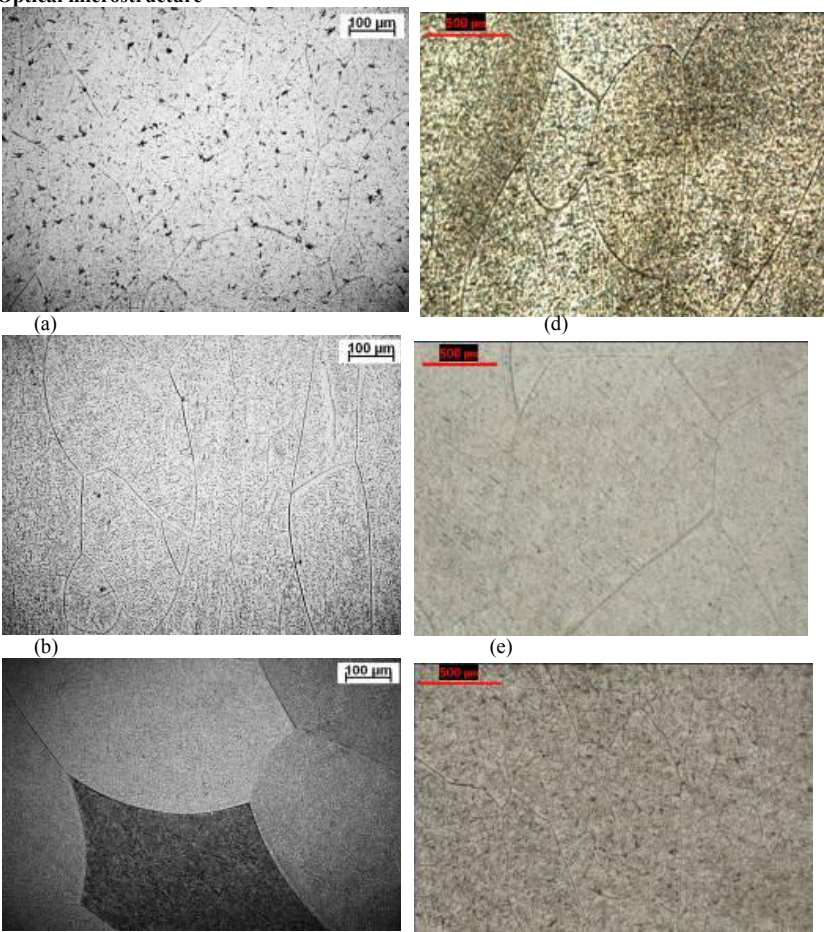

(c)
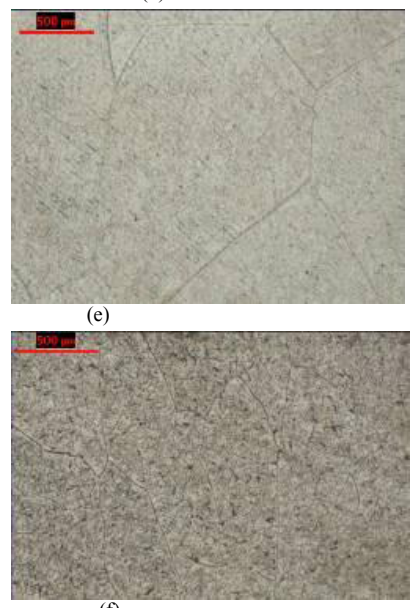

(f)

Figure 2: Optical photomicrograph of as cast $\mathrm{U}-\mathrm{Zr}$ alloys under bright field illumination; (a) as cast U-50wt\%Zr (b)as cast U-60wt\%Zr (c) as cast U-70wt\%Zr. (d) heat treated (550/24h) U-50wt\%Zr (e) heat treated(550/24h) $\mathrm{U}-60 \mathrm{wt} \% \mathrm{Zr}$ (f) heat treated(550/24h) U-70wt\%Zr. Note irregular grain size.

under bright field illumination. It is clear that the grains are relatively regular and large in size. In the heat treated (550/24) samples grain growth is observed. Grain size of the above micrographs are found out and given in table 3. It may be observed that enlargement of the grain size took place after heat treatment of the samples (Figure 2).

\section{SEM for as cast sample}

SEM of the cast samples were carried out and given in figure 3. Large grain size is observed in $\mathrm{U}-60 \mathrm{wt} \% \mathrm{Zr}$ and $\mathrm{U}-70 \mathrm{wt} \% \mathrm{Zr}$ samples.

\section{EDS for as cast sample}

EDS has been carried out on as cast sample. Each sample was analyzed three different locations to find out weight percentage of $U$ and $\mathrm{Zr}$ present and then average was taken as reported in table 4 . Table 5 provides the variation of actual weight of sample prepared and EDS calculated value. This shows variation is nominal.

\section{XRD analysis}

$\mathrm{XRD}$ result is given in figure 4 for all the alloys. At room temp, as per equilibrium diagram for $\mathrm{U}-50 \mathrm{wt} \% \mathrm{Zr}$, should contain only dphase. For U-60 and $70 \mathrm{wt} \% \mathrm{Zr}$, it should contain d phase and a Zr. Figure $4 \mathrm{a}$ shows the XRD of as cast sample. The sample contains mostly d-phase and $\alpha \mathrm{Zr}$. Two different colours present in the optical microstructure indicates present of two phases. The reason for difference observed in experiment result and phase diagram (Figure 1) for composition U-50 $\mathrm{wt} \% \mathrm{Zr}$, may be due to limitation of XRD, fast transformation of delta phase or not well defined equilibrium line. But for compositions U-60 and $70 \mathrm{wt} \% \mathrm{Zr}$, XRD detections are as per phase diagram.

Figure $4 \mathrm{~b}$ shows the XRD of heat treated $(550 / 24 \mathrm{~h})$ sample. After heat treatment the alloy samples had reached equilibrium state. This is seen in the XRD result. The samples mostly contain d-phase. Presence of single colour in the optical microstructure indicates presence of only one phase. For composition U-50 wt $\% \mathrm{Zr}$ result is matching with the phase diagram. However for composition U-60 wt $\% \mathrm{Zr}$ and U-70 wt\% $\mathrm{Zr}$ phase diagram (Figure 1) indicates presence of both $\mathrm{d}$ phase and a Zr. However, only d phase is observed in XRD results of both the compositions. This may be due to limitation of XRD (i.e. amount is so small that it is not possible to detect by XRD), fast transformation of delta phase or not well defined equilibrium line.

\section{Dilatometric analysis}

The intention of the dilatometric analysis is to find out the linear thermal expansion coefficients of the alloy composition. Figure 5a, $\mathrm{b}$ and $\mathrm{c}$ show the thermal expansion curves corresponding to as cast and heat treated samples. It could be seen from the figures that fore cast sample, during heating no phase transformation takes place up to around $430^{\circ} \mathrm{C}$. Then it shows a hump/depression indicating instability during thermal expansion. In case of heat treated $(550 / 24 \mathrm{~h})$ sample, no such hump/depression is visible. For as cast sample, during heating, $d$ phase while trying to attain equilibrium, some portion of it (d-phase) disassociates to zirconium i.e. $d \rightarrow d+Z r$ for as cast high $\mathrm{Zr}$ content $\mathrm{U}-\mathrm{Zr}$ alloy. Dissociation of d-phase ( $\mathrm{UZr} 2)$ is possible due to various reasons; one of the reason is presence of oxygen (as impurity) with the inert gas. At around $610^{\circ} \mathrm{C}$ and $620^{\circ} \mathrm{C}$ for as cast and heat treated sample respectively, are going back to gamma phase as indicated in the phase diagram. This indicates due to heating, cast sample has reached equilibrium condition. It can be concluded that for high $\mathrm{Zr}$ content $\mathrm{U}-\mathrm{Zr}$ alloy undergoes $\mathrm{d} \rightarrow \gamma$ transformation at around $610^{\circ} \mathrm{C}$ and $620^{\circ} \mathrm{C}$ during heating for as cast and heat treated sample respectively. For both as cast and heat treated sample the change in length is reasonably sharp indicating kinetically fast transformation. Eventually around $650^{\circ} \mathrm{C}$ complete $\gamma$-phase is obtained. So within a window of 5 minutes (considering heating rate as $5^{\circ} \mathrm{C} \mathrm{min}^{-1}$ ) phase
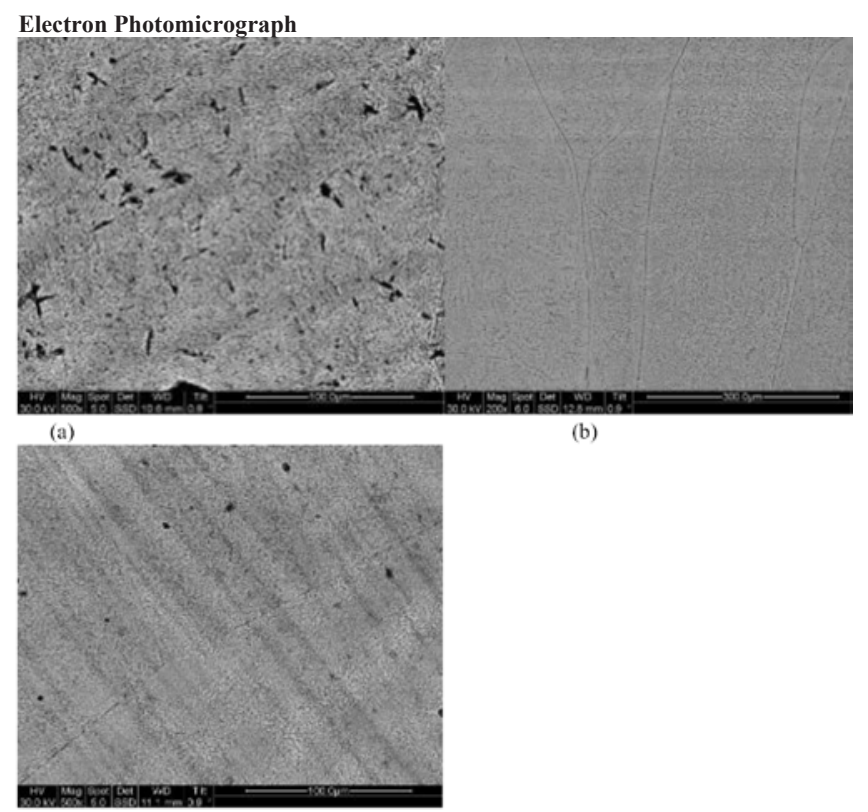

(b)

(c)

Figure 3: Back scattered electron photomicrograph of as cast $\mathrm{U}-\mathrm{Zr}$ alloys; (a) U-50wt\%Zr (b) U-60wt\%Zr (c) U-70wt\%Zr. 
Citation: Bagchi AC, Prasad GJ, Khan KB, Singh RP (2013) Physical Metallurgical Studies of Zr-Rich U-Zr Alloys. J Material Sci Eng 2:121. doi:10.4172/2169-0022.1000121

Page 4 of 6

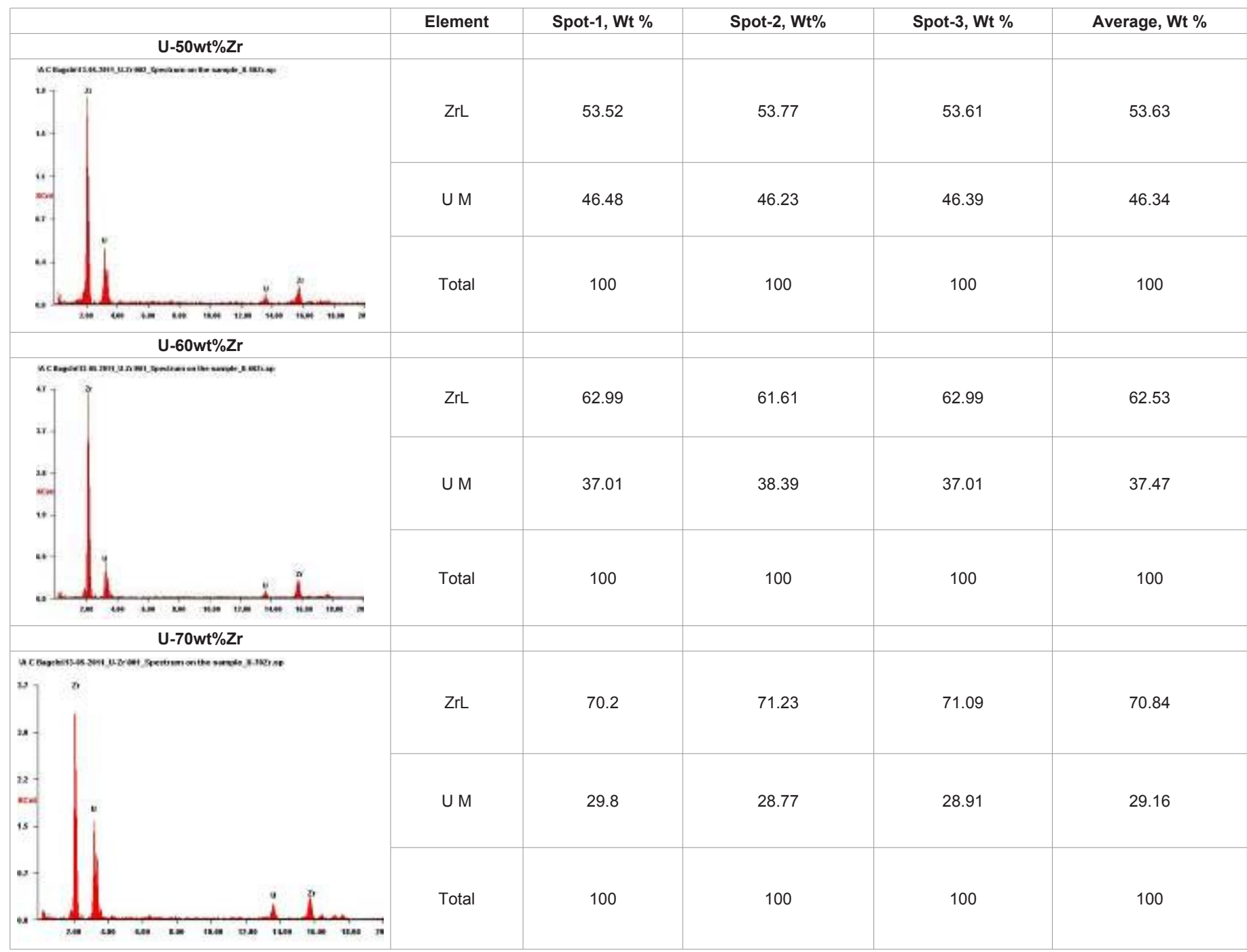

Table 4: Composition details on each sample found through EDS.

\begin{tabular}{|c|c|c|c|}
\hline Sr No & Composition & CTE $\left(30-600{ }^{\circ} \mathrm{C}\right)$ & $\begin{array}{c}{ }^{\circ} \mathrm{C} \\
/{ }^{\circ} \mathrm{C}\end{array}$ \\
\hline 1 & $\mathrm{U}-50 \mathrm{Zr}$ & $4.2418 \times 10^{-6}$ & $4.1110 \times 10^{-6}$ \\
\hline 2 & $\mathrm{U}-60 \mathrm{Zr}$ & $5.5953 \times 10^{-6}$ & $5.1082 \times 10^{-6}$ \\
\hline 3 & $\mathrm{U}-70 \mathrm{Zr}$ & $5.5996 \times 10^{-6}$ & $5.93945 \times 10^{-6}$ \\
\hline
\end{tabular}

Table 5: Coefficient of thermal expansion (CTE) for $\mathrm{U}-\mathrm{Zr}$ alloy (heat treated to $550^{\circ} \mathrm{C}$ for $24 \mathrm{hrs}$ then quenched in water).

transformation took place. Slope of as cast and heat treated samples are different. This is because cast sample has not reached equilibrium stage due to relatively fast cooling during casting. While due to prolong heating, heat treated sample has reached equilibrium stage indicating comparatively a lower slope of the expansion curve. Incidentally for all the as cast sample, hump starts at $430^{\circ} \mathrm{C}$ and ends after $600^{\circ} \mathrm{C}$. It may be noted that $\mathrm{U}-60 \mathrm{wt} \% \mathrm{Zr}$ (Figure $5 \mathrm{~b}$ ), curve showing some irregularity with respect to other two compositions may be due to in-homogeneity in the sample.

Co-efficient of thermal expansion: The dilatometric curve presented in figure $5 \mathrm{~d}$ shows two distinct phase transformations at around $600^{\circ} \mathrm{C}$ and $630^{\circ} \mathrm{C}$ ( $\gamma$-phase). These curves can be fitted by a third degree polynomial and obtain a mathematical expression for the coefficient of thermal expansion from $30^{\circ} \mathrm{C}(303 \mathrm{~K})$ to $600^{\circ} \mathrm{C}(873 \mathrm{~K})$
( $\mathrm{Zr}$ and d-phase). These expressions for different as-cast $\mathrm{U}-\mathrm{Zr}$ alloys are as follows:

\section{For U-50Zr:}

$30-600{ }^{\circ} \mathrm{C}$

[DL/L0]. $100=-0.00344+1.9783710-4 \mathrm{~T}+4.72704 \cdot 10-7 \mathrm{~T} 2-$ $2.0469410-10 \mathrm{~T} 3$

$650-1000{ }^{\circ} \mathrm{C}$

[DL/L0].100 $=0.12321+1.1574610-4 \mathrm{~T}+3.4888610-7 \mathrm{~T} 2-$ 1.34308 10-10 T3

\section{For U-60Zr:}

$30-600{ }^{\circ} \mathrm{C}$ 


\section{XRD Pattern}

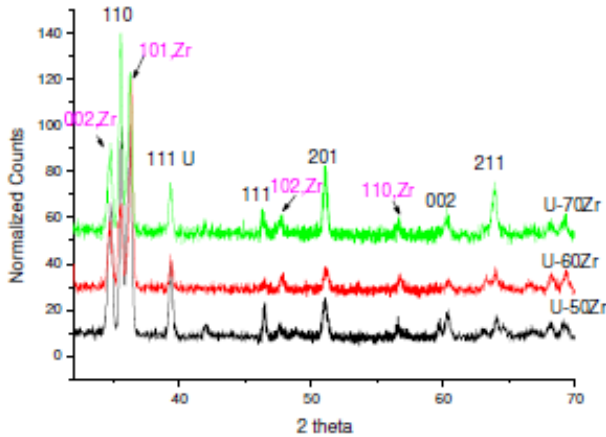

(a)

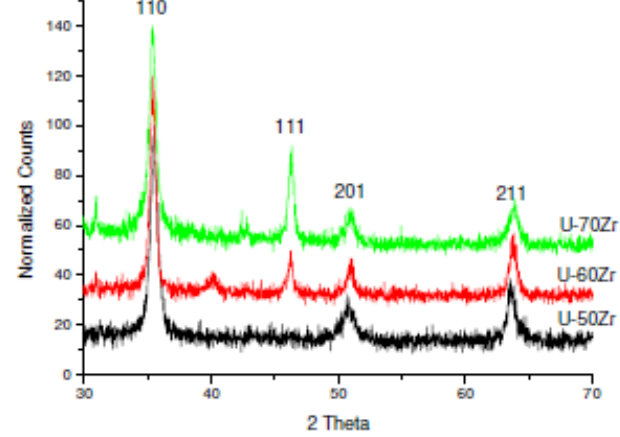

(b)

Figure 4: Combined plot of XRD data for (a) As cast sample; (b) same sample with $24 \mathrm{hrs}$ heated at $550^{\circ} \mathrm{C}$ and then quenched in water. The peaks aredelta and zirconiumfor as cast sample and deltafor heat treated (550/24h) sample.

\section{Thermal Expansion Curves}

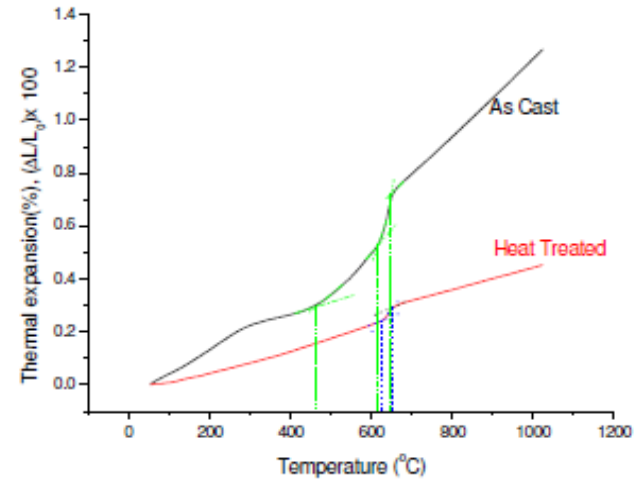

(a)U-50wt\%Zr

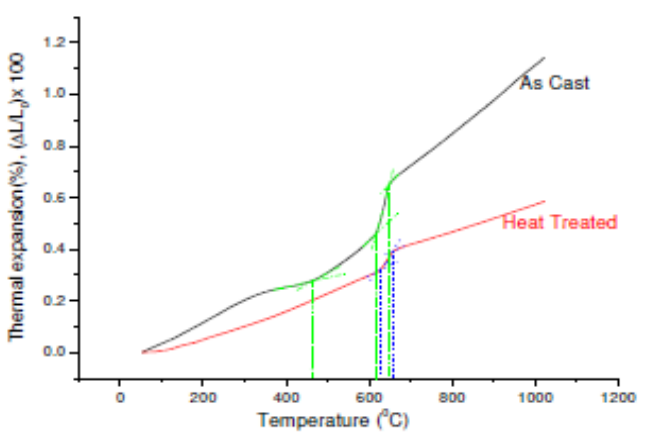

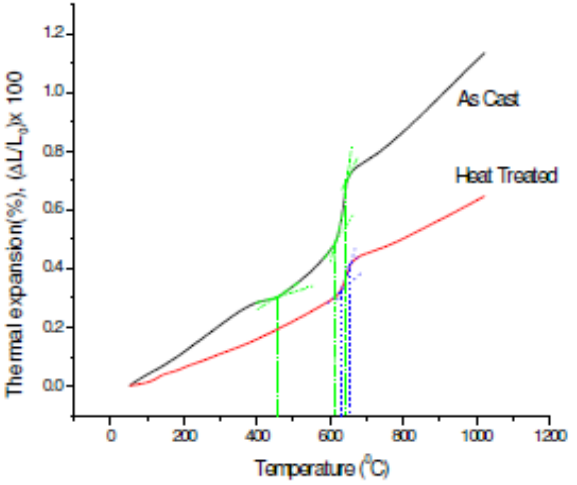

(b)U-60wt\%Zr

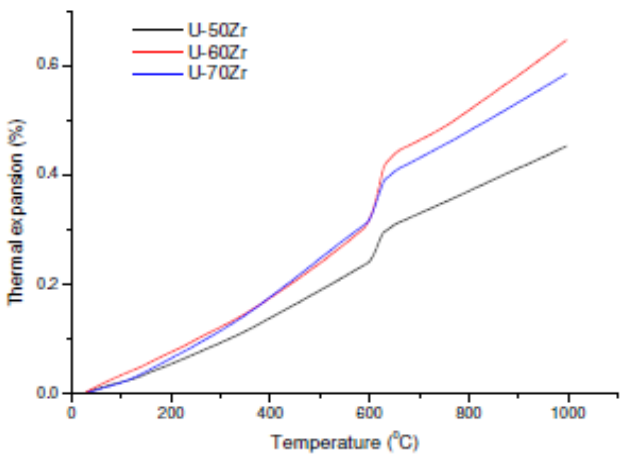

(c) U-70wt\%Zr (d) combined curve ror neat treatea sampıe

Figure 5: Thermal expansion curve for (a) U-50wt\% $\mathrm{Zr}(\mathrm{b}) \mathrm{U}-60 \mathrm{wt} \% \mathrm{Zr}(\mathrm{c}) \mathrm{U}-70 \mathrm{wt} \% \mathrm{Zr}$ alloy as cast Samples andheat treated samples (heated to $550^{\circ} \mathrm{C}$ for $24 \mathrm{hrs}$ and quenched) and (d) Combined thermal expansion as a function of temperature for UZr heat treated alloy. 
Citation: Bagchi AC, Prasad GJ, Khan KB, Singh RP (2013) Physical Metallurgical Studies of Zr-Rich U-Zr Alloys. J Material Sci Eng 2:121. doi:10.4172/2169-0022.1000121

Page 6 of 6

$[\mathrm{DL} / \mathrm{L} 0] .100=-0.00828+4.1304510-4 \mathrm{~T}-7.0584610-8 \mathrm{~T} 2+$ 4.57617 10-10 T3

$650-1000{ }^{\circ} \mathrm{C}$

[DL/L0]. $100=1.0336-0.00279 \mathrm{~T}+3.7986210-6 \mathrm{~T} 2-1.3908610-9$ T3

\section{For U-70Zr:}

$30-600^{\circ} \mathrm{C}$

[DL/L0]. $100=-0.00606+1.9630110-4 \mathrm{~T}+8.1302510-7 \mathrm{~T} 2-$ 3.99648 10-10 T3

$650-1000{ }^{\circ} \mathrm{C}$

[DL/L0]. $100=0.26383-9.8655410-5 \mathrm{~T}+6.1911510-7 \mathrm{~T} 2-$ 1.97397 10-10 T3

Where, temperature $T$ is in $\mathrm{K}, L 0$ is the initial length (at $298 \mathrm{~K}$ ) and $\mathrm{D} L$ is the difference between the instantaneous length (at any temperature $T$ ) and $L 0$. It can be seen from figure 5 that higher $\mathrm{Zr}$ concentration in the alloy increases the thermal expansion. Bauer [4] have determined the linear thermal expansion coefficients of uranium, zirconium and alloys containing up to $100 \%$ zirconium with different sample history. Linear thermal expansion coefficients of uranium and zirconium are affected by preferred orientations developed by fabrication procedures. Therefore, when Comparing data it is important to know the fabrication and heat treatment histories of the specimens.

\section{Conclusions}

With the help of the preceding discussions it could be summarized that $\mathrm{Zr}$-rich $\mathrm{U}-\mathrm{Zr}$ alloys exhibit d-phase along with $\mathrm{U}$ and $\mathrm{Zr}$ at room temperature in as-cast condition. Thermal expansion of the alloy increases with increasing $\mathrm{Zr}$ concentration.

Different properties of the alloys have been reported. It is observed that there is no dimensional stability for as cast sample with respect to heat treated sample. From this observation it can be concluded that as cast fuel rod of U-50wt\%Zr, U-60wt\%Zr and U-70wt\% Zr are dimensional unstable. This has to be heat treated to obtain a stable structure. However these alloys can be used as dispersion fuel where it is expected to average out over volume fraction depending upon particle size and their distribution.

\section{Acknowledgements}

The authors are grateful to Dr. T.R.G. Kutty, Head, FPES, RMD and his group for SEM and dilatometric analysis. Dr. C.B. Basak has provided colossal support on work planning. Shri S. Das, Uranium Extraction Division has allowed using his equipments for sample melting and cutting. And, last, but not the least, thanks to the members of ED\&AS, AFD for their help on sample preparation.

\section{References}

1. Park JM, Kim KH, Sohn DS, Kim CK, Hofman GL (1999) Characterization of $\mathrm{U}-\mathrm{Nb}-\mathrm{Zr}$ dispersion fuel prepared by centrifugal atomization process. $\mathrm{J} \mathrm{Nucl}$ Mater 265: 38-43.

2. Savchenko AM, Vatulin AV, Morozov AV, Dobrikova IV, Ershov SA, et al (2006) Inert matrix fuel with low melting point zirconium brazing alloys. J Nucl Mater 352: 334-340

3. Savchenko A, Konovalov I, Vatulin A, Morozov A, Orlov V, et al. (2007) Dispersion type zirconium matrix fuels fabricated by capillary impregnation method. J Nucl Mater 362: 356-363.

4. Bauer AA (1959) Report No. BMI-1350, Battelle Memorial Institute, UC-25 Metallurgy and ceramics, TID-4500, $15^{\text {th }}$ Edn.

5. (1958) Proceedings of the Second United Nations International Conference on the Peaceful Uses of Atomic Energy: Held in Geneva. Properties of reactor materials, United Nations.

6. Fairman HE, Kelly A (2004) ASM Metals Handbook.

7. (1955) Report No. BMI-1030 An Evaluation of Data on Uranium-Zirconium Alloys.

8. Lagerberg G (1963) Phase transformations in a uranium-zirconium alloy containing 2 weight per cent zirconium. J Nucl Mater 9: 261-276.

9. Basak C, Prasad GJ, Kamath HS, Prabhu N (2009) An evaluation of the properties of As-cast U-rich U-Zr alloys. J Alloy Compd 480: 857-862.

10. Hills BF, Butcher BR, Howlett BW (1965) The effect of cooling rate on the decomposition of the $\mathrm{y}$-phase in uranium-zirconium alloys. J Nucl Mater 16 25-36.

11. Basak CB (2011) Microstructural evaluation of U-rich $U-Z r$ alloys under nearequilibrium condition. J Nucl Mater 416: 280-287.

12. Zegler ST, U.S. Atomic Energy Commission, Argonne National Laboratory (1962) The Uranium-Rich end of the Uranium-Zirconium system. Argonne National Laboratory, USA.

13. Voort GV (2004) ASM Handbook: Metallography and Microstructures. ASM International. 